\title{
South Florida ornamental plant grower perspectives: water conservation management practices 1
}

\author{
Kati W. Migliaccio, Edward Evans, Jonathan H. Crane, Bruce Schaffer, Yuncong Li, and Rafael \\ Muñoz-Carpena ${ }^{2}$
}

\section{Introduction}

The 2002 Census of Agriculture indicated that Miami-Dade County had about 90,000 acres of agriculture, distributed among 2,244 growers.

Sixty-three percent of ornamental nurseries were less than 10 acres and $89 \%$ were less than 50 acres in size. In 2002, the market value of agricultural products from Miami-Dade County was about $\$ 578$ million, with an overall economic impact in excess of $\$ 2$ billion. The ornamental plant industry, comprising decorative plants, shrubs, bushes, and trees is the single largest segment of the county's agricultural industry. In 2002, the value of sales amounted to $\$ 434.4$ million representing over $75 \%$ of the total value of agricultural production for the County.

There are about 11,000 acres of ornamental plant production in Miami-Dade County consisting of three general types of nurseries: a) field nurseries, b) container nurseries, and c) shade or greenhouse nurseries. Most of the nurseries are located south of the Tamiami Trail (SW $8^{\text {th }}$ Street) and vary in size, from operations that are less than two acres to very large operations with more than 100 acres. The 2002 Census indicates a total of 714 certified nurseries in the county, but there is reason to believe that the total number of nurseries far exceed this amount (personal communication with Dr. Joe Garofalo).

Although the industry faces several pressing issues (including high production costs, lack of available labor, pests and diseases, natural and disaster avoidance and mitigation), water and fertilizer management are emerging as major concerns. This is due, in part, to increasing urbanization in the area and the presence and protection of sensitive ecosystems such as the Everglades and Biscayne National Parks. In addition, the region has historically experienced periods of extended droughts which threaten production capabilities thus making water conservation practices an integral component of future development plans for the industry.

It is within this context that this survey (the first in a series of two) was designed to assess changing views of local agricultural residents (Miami-Dade County growers) over the next three years regarding

1. This document is ABE 369, from the Department of Agricultural and Biological Engineering, Florida Cooperative Extension Service, Institute of Food and Agricultural Sciences, University of Florida. First Published: July 2006. Please visit the EDIS Web site at http://edis.ifas.ufl.edu.

2. Kati W. Migliaccio is Extension Specialist, Tropical Research and Education Center (TREC), Homestead, FL; Edward Evans, Extension Specialist, TREC, Homestead, FL; Jonathan H. Crane is Extension Specialist, TREC, Homestead, FL; Bruce Shaffer is Professor, TREC, Homestead, FL; Yuncong Li is Extension Specialist, TREC, Homestead, FL; Rafael Muñoz-Carpena is Extension Specialist, Agricultural and Biological Engineering, Gainesville, FL

The Institute of Food and Agricultural Sciences (IFAS) is an Equal Opportunity Institution authorized to provide research, educational information and other services only to individuals and institutions that function with non-discrimination with respect to race, creed, color, religion, age, disability, sex, sexual orientation, marital status, national origin, political opinions or affiliations. U.S. Department of Agriculture, Cooperative Extension Service, University of Florida, IFAS, Florida A. \& M. University Cooperative Extension Program, and Boards of County Commissioners Cooperating. Larry Arrington, Dean 
water quantity and quality management practices. Information from the survey will be used to tailor future research and extension programs to educate the public and to provide ornamental plant growers with a range of cost effective technologies that will potentially enable them to satisfy environmental concerns while still remaining profitable.

\section{Methods}

The Water Conservation Survey (WCS) was developed by extension faculty (agents and specialists) at the Tropical Research and Education Center (TREC) and the Miami-Dade Cooperative Extension Service, Homestead, FL. Once completed, the survey was submitted to the University of Florida Institutional Review Board for approval.

Participation was voluntary and anonymity was assured.

All Survey questions required either multiple choice or "Yes/No" answers. The questions were arranged in 3 categories: background (8 questions), water quality and quantity opinions related to the home (7 questions), and water quality and quantity related to agriculture (12 questions). The background category was designed to collect general information on the respondents such as their acreage, experience, and age. The water quality and quantity opinions related to the home category were included to gain perspective into the everyday lifestyle of the respondents and their activities related to water conservation. The water quality and quantity related to agriculture category was designed to assess the current perspectives and practices of the respondents, focusing on best management practices (BMPs) for water conservation.

The survey was mailed to ornamental growers identified on a mailing list provided by the Miami-Dade County Cooperative Extension Service. In addition, an on-line survey was posted on Florida Agricultural BMP BLOG (FABB) (http://fabb.ifas.ufl.edu). The survey was further advertised to local growers through their local organizational meetings. The survey was dispersed in February 2006 and results received by the end of March 2006 were tabulated. Approximately 130 surveys were mailed to ornamental plant growers. Of these, a total of 38 were returned resulting in a response rate of $29 \%$. This was within the anticipated range of responses (10-50\% reported for similar surveys, Nachmias and Nachmias, 1976; Neuman, 1997; Donan et al., 2000).

\section{Current Demographics}

Seventy-six percent of the respondents indicated that that they relied primarily on their nurseries as the basis of generating their income, although $82 \%$ consider themselves full time growers.

Most of the nurseries (45\%) were between 10 to 49 acres. Eighty-four percent of ornamental growers reported their acreage as less than 49 acres.

The survey also indicated $69 \%$ of ornamental plant growers were over the age of 51 . Only $5 \%$ of ornamental plant growers reported their age as 40 years-old or less.

\section{Water Quality and Quantity Opinions: Everyday Lifestyle}

Ornamental plant growers indicated that they actively conserved water in their homes. For example, at least $61 \%$ of respondents reported not running the water faucet continually while brushing their teeth, not leaving lawn water hoses on longer than necessary, not running the dishwasher unless full, and not taking exceedingly long showers. Eighty-seven percent of ornamental plant growers also were interested in learning additional lifestyle changes that would conserve water. However, 29\% felt that the actions that they practice to conserve water would not make a long-term difference in water conservation.

The initiative shown by ornamental plant growers to participate in water conservation practices in their home suggests some personal acknowledgement of the value of our water supplies (such as personal health, economic, or environmental). The presence of this perception is encouraging and is useful groundwork upon which to introduce and implement water conservation practices into their agricultural enterprises. 


\section{Water Quantity and Quality Practices: Agriculture}

Water conservation in agriculture is not a new concept. In fact, Best Management Practice (BMP) manuals for Florida's different commodities and regions have been developed that are meant to assist producers with implementing water conservation practices. In addition, BMP implementation is being encouraged by the Florida Department of Environmental Protection (FDEP) through their incentive of Presumption of Compliance (for more information on the BMP process, see Migliaccio et al., 2006). For this reason, questions regarding BMPs and Presumption of Compliance were included in the survey. Results showed that $71 \%$ of orgnamental growers would implement BMPs under the FDEP presumption of compliance incentive. However, 50\% reported they would not spend more than $\$ 500$ to implement the BMPs. This suggests that some cost share program would be essential for about half the growers to implement BMPs, especially those of greater monetary investment. On the other hand, $85 \%$ indicated a willingness to implement BMPs if such practices were shown to be economically beneficial. These results suggest the importance of economic analysis of BMPs and the transfer of this information to growers for their assessment and incorporation into everyday practices.

\section{Water Quantity BMPs}

Water quantity BMPs refer to management practices that conserve the quantity of water used. The goal of implementing water quantity BMPs is to use water more efficiently so that less volume is required.

Several practices were suggested in the survey as potential water saving measures. Each of these was identified as being used or not used in the growers nurseries in the past 5 years (Table 1).

In addition, each grower ranked the applicability of each of these practices (from Table 1). Ornamental plant growers identified the least applicable practice as growing mainly drought-tolerant plant species with $16 \%$ reporting this practice as somewhat applicable or very applicable. This result contrasted with findings reported by
Muñoz-Carpena et al. (2003) who found 45\% of ornamental plant growers were growing drought-tolerant plant species. Among the factors which could have contributed to the reduction of respondents using this practice are: a shift in regional market supplied (movement from a supply for local customers to those in other regions of the US) or a shift in production type (from yard plants to house plants).

Table 1. Water quantity practices and survey response by ornamental plant growers indicating their use of practices

\begin{tabular}{|c|c|}
\hline Management practice & $\begin{array}{c}\% \text { of growers } \\
\text { using the } \\
\text { practice }\end{array}$ \\
\hline $\begin{array}{l}\text { Growing mainly drought-tolerant } \\
\text { plant species }\end{array}$ & 11 \\
\hline $\begin{array}{l}\text { Irrigating mainly in the early } \\
\text { morning or late evening }\end{array}$ & 79 \\
\hline $\begin{array}{l}\text { Monitoring plant growth stages } \\
\text { (phenology) and irrigating } \\
\text { accordingly }\end{array}$ & 61 \\
\hline $\begin{array}{l}\text { Monitoirng container or field soil } \\
\text { moisture }\end{array}$ & 53 \\
\hline $\begin{array}{l}\text { Monitoring the weather and only } \\
\text { irrigating during periods of dry } \\
\text { weather }\end{array}$ & 55 \\
\hline None & 0 \\
\hline Other & 11 \\
\hline
\end{tabular}

The most applicable water conservation practice identified in survey results was irrigating mainly in the early morning or late evening. Fifty-five percent of ornamental plant growers indicated that this practice was very applicable with another $24 \%$ marking it as somewhat applicable. This was an increase to previous survey results (Muñoz-Carpena et al., 2003) which indicated that $34 \%$ of ornamental plant growers irrigated in the morning or late evening. The increase in implementation of this simple practice may be due to the increasing awareness of growers regarding water conservation practices and their benefits.

Monitoring of plant growth stages was selected by $53 \%$ as a very applicable conservation practice. This suggests that growers would be interested in information on the nutrient and water needs of 
different plants at different growth stages to better manage their resources.

Measuring field soil moisture was considered a very applicable water conservation practice by $53 \%$ of ornamental plant growers; similarly, $53 \%$ indicated that monitoring weather was a very applicable water conservation practice. This coincided with additional survey results which showed that $55 \%$ of ornamental plant growers had monitored local weather to regulate irrigation within the past 5 years. A similar percentage of growers reported using soil moisture monitoring to determine irrigation needs $(53 \%)$ over the same time period.

\section{Water Quality BMPs}

Water quality BMPs refer to practices that improve the quality of water by minimizing the concentration of contaminants (or pollutants). The goal of water quality BMPs is to protect water supplies so that they are sufficient for meeting designated uses.

Water quality BMPs were assessed by the growers responding to the survey with regards to their use of the practice in the past 5 years (Table 2).

Table 2. Water quality practices and survey response by ornamental plant growers indicating their use of practices

\begin{tabular}{|c|c|}
\hline Management practice & $\begin{array}{c}\% \text { of growers } \\
\text { using the } \\
\text { practice }\end{array}$ \\
\hline $\begin{array}{l}\text { Application of nutrients based on } \\
\text { soil sampling }\end{array}$ & 32 \\
\hline $\begin{array}{l}\text { Application of nutrients based on } \\
\text { plant tissue analysis }\end{array}$ & 24 \\
\hline $\begin{array}{l}\text { Monitoring local weather to avoid } \\
\text { application of agrochemicals } \\
\text { immediately preceding a rainfall } \\
\text { event }\end{array}$ & 68 \\
\hline $\begin{array}{l}\text { Application of agrochemicals using } \\
\text { a calibrated chemical injector with } \\
\text { drip or micro irrigation }\end{array}$ & 26 \\
\hline None & 8 \\
\hline Other & 5 \\
\hline
\end{tabular}

Growers provided additional information on the practices listed in Table 2 by indicating their applicability. The most applicable practice (with
$47 \%$ responding as "very applicable") was monitoring of local weather conditions to minimize use of agrochemicals immediately preceding a rainfall event. For the three remaining practices (application of nutrients based on soil sampling, application of nutrients based on plant tissue analysis, and application of agrochemicals using a calibrated chemical injector) results were inconclusive with 13 to $24 \%$ responding as very applicable and 24 to $34 \%$ responding as not applicable.

\section{Extension - Information Transfer}

The most common factor identified (66\%) as influencing implementation of a BMP was cost (66\%). However, $21 \%$ of the respondents indicated that knowledge regarding a technology could prevent their implementation of a practice.

As BMPs evolve, new information and techniques are developed. This new, valuable information is then transferred to the local agricultural community. The different techniques used to transfer information often vary, from one-on-one meetings to field day demonstrations, to information posted on the Internet.

Because multiple techniques are used, ornamental plant growers were also asked in the survey to indicate a preferred method of information transfer. Choices included Extension fact sheets, field days, short course, and local grower implementation or demonstrations. Results of the survey suggested that Extension fact sheets (42\%) and short courses (42\%) were preferred. These were closely followed by field days and demonstrations at research centers and extension offices (39\%).

\section{Summary}

This survey was conducted to determine the current perceptions of local ornamental plant growers with regards to water conservation practices. Results indicated that growers are predominantly working on less than 49 acres (84\%), predominantly over the age of $51(69 \%)$, with a majority (82\%) considering themselves full-time growers. The majority of survey respondents practice water saving measures at home and indicated interest in learning about additional measures. Most ornamental plant growers (71\%) 
indicated an interest in implementing BMPs under the FDEP presumption of compliance incentive. The predominant practice already in use by ornamental plant growers as a water quantity BMP was irrigating in the early morning and late evening; and as a water quality BMP was monitoring of weather to determine the best time apply agrochemicals. Currently, the method being used is to monitor weather conditions and manually adjust irrigation as needed. An alternative to this approach would be to use an automated system (such as an irrigation schedule based on historic evapotranspiration or a system that monitors weather realtime and irrigates accordingly). Transfer of water conservation information is most beneficial to growers if presented in an Extension fact sheet (i.e., EDIS publication) or a short course (1 to 2 hours).

\section{References}

Donan, A.H., R. Kreutzwiser, and R. de Loë. 2000. Rural water use and conservation in southwestern Ontario. J. Soil and Water Conservation 55:161-171.

Census of Agriculture. 2002. U.S. Census of Agriculture, United States Department of Agriculture, Washington, D.C.

Migliaccio, K. W. and B. J. Boman. 2006. Total Maximum Daily Loads and Agricultural BMPs in Florida. ABE362, Agricultural and Biological Engineering Department, Florida Cooperative Extension Service, Institute of Food and Agricultural Sciences, University of Florida.

http://edis.ifas.ufl.edu/AE388

Muñoz-Carpena, R., J. H. Crane, G. D. Israel, and J. Garofalo. 2003. Ornamental growers water use and conservation practices in Miami-Dade County. ABE347, Agricultural and Biological Engineering Department, Florida Cooperative Extension Service, Institute of Food and Agricultural Sciences, University of Florida. http://edis.ifas.ufl.edu/AE260

Nachmias D. and C. Nachmias. 1976. Research Methods in the Social Sciences. St. Martins Press, New York.
Neuman, L.W. 1997. Social Research Methods: Qualitative and Quantitative Approaches. $3^{\text {rd }}$ ed. Allyn and Bacon Publ., Boston.

TREC Strategic Plan. 2005. Available at http://trec.ifas.ufl.edu/doc/StrategicPlan.pdf, Accessed on May 2, 2006. 